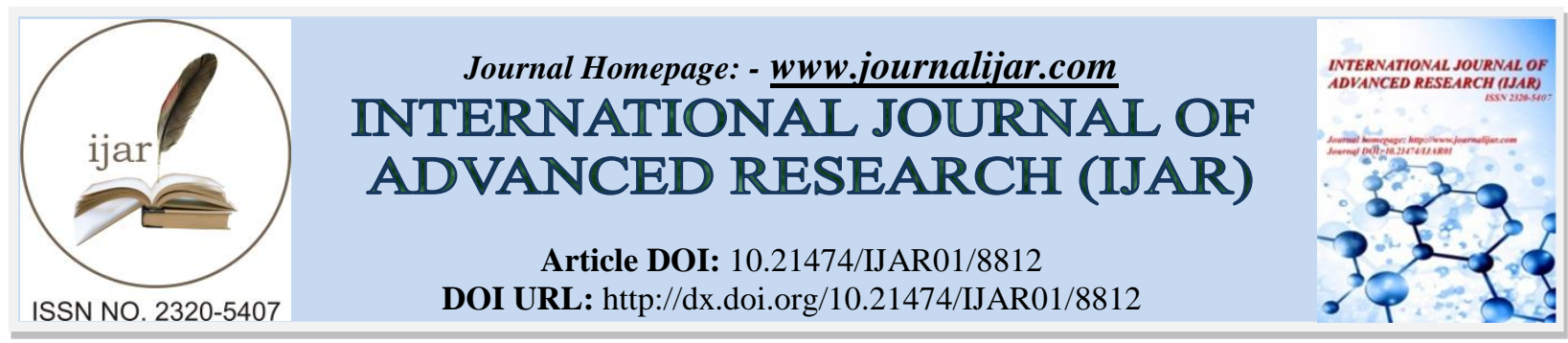

RESEARCH ARTICLE

\title{
ASSOCIATION OF BODY MASS INDEX WITH DEPRESSION AMONG PRIMARY INFERTILE WOMEN.
}

Shalan Joodah Rhemah Al-Abbudi M.B.Ch.B., F. I. B. M. S. Psych.

Consultant Psychiatrist, Head of Psychiatry Department, Imamain Kadhimain Medical City, Baghdad, Iraq.

\section{Manuscript Info}

Manuscript History

Received: 05 February 2019

Final Accepted: 07 March 2019

Published: April 2019

Key words:-

depression; infertility; BMI; DSM-V; SRQ-20.

\begin{abstract}
Background: Depression is most frequent mood disorder comorbid with physical illness. Objectives: to determine the relationship between Body Mass Index (BMI) and depression among women with primary infertility Methods: a cross-sectional study included infertile women attending fertility center. Socio-demographic and clinical variables were compiled including BMI. Self-Reporting Questionnaire (SRQ-20) to identify mental illnesses; DSM-V criteria for depression and Hamilton-17 Scale for severity of depression, were used. Results: $80 \%$ of infertile women were depressed. BMI was significantly correlated with age, education, monthly income, duration of marriage, smoking, medication, chronic illness, and religion $(P<0.001)$. Depression was significantly associated with BMI $(P<0.001)$. Conclusion: study found high prevalence of depression among infertile women of statistically significant correlation with BMI.
\end{abstract}

Copy Right, IJAR, 2019,. All rights reserved.

\begin{abstract}
Abbreviation:-
BMI: body mass index, SRQ-20: self-rating questionnaire, HAM-17: Hamilton depression scale-17, DSM-V: diagnostic and statistical manual version five, BID: body image dissatisfaction, SPSS: Statistical package of social sciences.
\end{abstract}

\section{Introduction:-}

Obesity is a rising public health issue all over the world. Obesity is a disorder of inactivity which is result from sedentary life style ${ }^{1}$. Obesity is a multifaceted illness on the biological basis which includes genetic and biological components that are involved in normal body growth, eating habits, energy expenditure, and adipose tissue function ${ }^{2}$. Researchers focused on the factors influencing the development of obesity and the role of hormones and intestinal peptides. Milaneschi et $\mathrm{al}^{3}$, found that levels of leptin are higher in obese men. This finding supports the biological link between obesity and depression which may leads to negative outcomes ${ }^{4}$. Experts attributed that increasing depression incidence is related to increasing prevalence of obesity ${ }^{5}$. Depression is most frequent mood disorder comorbid with physical illness, which can be psychogenic or reactive ${ }^{6}$. Characteristic features of depression include loss of low self-esteem, interest, guilt feelings, sadness, disturb sleep and appetite, poor concentration, and tiredness. Depression may be recurrent episodes or long-lasting course, with disturbed function of daily life, work and school. Severe depression may end with suicide ${ }^{7}$. The clinical and statistical significance of the link between obesity and mental health has been established ${ }^{8}$. Depression and Anxiety are found to be significantly associated with obesity. However, it is difficult to establish causality in one direction between obesity, anxiety, and depression ${ }^{9}$. The complexity of obesity as a public health problem, especially as it relates to mental health, is 
increased by demographic disparities. Sex, race, ethnicity, education, and socioeconomic differences are each predictors of a person being obese ${ }^{8}$. On the other hand depression is a mood disorder that affects the mental health. Given the high prevalence of depression and the significant burden of the disease on the individual, health system, and society, adopting appropriate methods to identify risk factors, prevention, treatment, and management of this illness is a must ${ }^{10}$. Affecting the mental health in turn disturbs individual's social and physical health. Depression leads to disruption in job performance and social and interpersonal relations ${ }^{11}$. The relationship between obesity and depression is complex. There are several theories about how the two are linked. Behavioral mechanisms, such as functional impairment and repeated dieting, cognitive mechanisms, such as body image dissatisfaction (BID) and poor self-rated health, and social mechanisms, such as stigma, may all play a role in the pathway from obesity to depression $^{12}$.

People experiencing fertility problem are almost twice as likely to suffer from depression as the general population. Depression significantly affects the quality of life of infertile couples and consequently, these disorders deserve more clinical attention ${ }^{13}$. Infertile couples experience chronic stress each month in case of the failure of fertilization $^{14}$. Several researchers have claimed that in the presence of stressors, women use concentrated confrontation on excitement more often compared to men ${ }^{15}$. The findings of one study in this regard indicated that $48 \%$ of infertile women and $23.8 \%$ of infertile men suffered from depression, while $44 \%$ of infertile women were diagnosed with psychological disorders ${ }^{14}$. This study was done to determine the relationship between Body Mass Index (BMI) and depression among women with primary infertility.

\section{Patients and Methods:-}

Design and setting: This is a cross-sectional study conducted on women with primary infertility attending Um AlBaneen fertility center, Imamain Kadhimain Medical City, Baghdad, Iraq. Data collected during the period March, 1st, 2014 to September, 1st, 2017.

Study Population and Sampling Technique: The study included women attending the fertility center during the data collection time. A systematic random sampling technique was applied, where every other 3rd patient entering the center who accepts to participate in the study and to have the interview was selected.

Inclusion criteria: all women with primary infertility of any age who welcomed participation were included. Exclusion criteria: Women with history of inability to conceive of less than 12 months, current serious or unstable medical illnesses that cannot complete the interview, not cooperative, and who did not give their consent to participate were exclude from the study.

Data collection Tools: sociodemographic variables and clinical characteristics of women were compiled using a questionnaire filled through a direct interview. List contained height and weight, and the body mass index was calculated as $\left(\mathrm{BMI}=\right.$ square of height $\mathrm{m}^{2} /$ body weight $\left.\mathrm{kg}\right)$. Mental status was assessed using the SRQ-20 scale (self- reporting questionnaires) that was developed by the WHO and used in many countries. According to previous studies conducted in Iraq, the cut-off point was seven ${ }^{16}$. Women with positive results were assessed for the presence of depression using the DSM-V criteria of depression". Women with "depression" were further assessed for the severity of depression using the Hamilton scale ${ }^{7}$.

Definition of variables: The independent variables evaluated to explain depression were socio demographics (age, education, occupation, religious status, and BMI), smoking habits, and duration of marriage. Statistical Analysis: Statistical package of social sciences (SPSS) version 20 was used for data entry and analysis. Categorical variables were tested using chi square test. $\mathrm{P}<0.05$ was considered statistically significant. Ethical Issue: Official approvals were granted from the officials in the study setting. Informed consent was obtained from each participant to be included in this study. Names were kept anonymous and interviews were conducted with full privacy.

\section{Results:-}

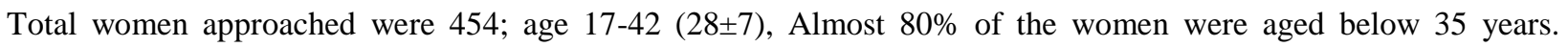
Monthly income was 150000-150000000 Iraqi dinars (584000 \pm 310000$)$, Almost 95\% of women from low and middle monthly income. Duration of marriage $1-20$ years $(7 \pm 4.5)$, 85\% were below 10 years. Nearly one third of women were of primary education. Employed women about $4 \%$ and all other were house wives. Smoker women were $7.5 \%$. About $94 \%$ were taking different medication. Nearly half of women were mild religious. 
The correlation of BMI of women participated in this study were strongly significant with age, education, occupation, monthly income, duration of marriage, smoking, medication, chronic illness, and religion $(P<0.001)$ (Table 1)

The correlation of depression was statistically significant with education $(P<0.001)$, monthly income $(P=0.005)$, duration of marriage $(P<0.001)$, smoking $(P=0.001)$, medication $(P=0.010)$, chronic illness $(P=0.010)$, religion $(P<0.001)$, and BMI $(P<0.001)$. (Table 2)

The height of women $142-174 \mathrm{~cm}(161 \pm 6.8 \mathrm{~cm})$, the weight of women $50-130 \mathrm{~kg}(73 \pm 15 \mathrm{~kg}), \mathrm{BMI} 17.5-42.9 \mathrm{~m}^{2} / \mathrm{kg}$ $(28 \pm 5.4)$, BMI < 25 were 158 (49.4\%), BMI 25-30 were 50 (15.6\%), BMI > 30 were $112(35 \%)$. (Table 3)

SRQ-20 positive results were (256) 80\%. Women met the DSM-V criteria of depression were (256) 80\%. According to Hamilton scale of severity of depression; mild (58) $18.1 \%$, moderate (40) $12.5 \%$, severe (82) $25.6 \%$, and very severe depression (76) $23.8 \%$.

BMI < 25 were $158(49.4 \%)$, about $78.5 \%$ of them were depressed. BMI $25-30$ were $50(15.6 \%)$, all of them were depressed $(100 \%)$. BMI > 30 were $112(35 \%)$, about $73.2 \%$ were depressed.

The correlation of BMI with SRQ-20 results, DSM-V criteria of depression, and the Hamilton severity of depression were strongly statistical significant results $(P<0.001)$ (Table 4$)$

Table 1: frequency, percentage, and correlation of BMI with sociodemographic variables

\begin{tabular}{|c|c|c|c|c|c|c|c|}
\hline \multirow{2}{*}{$\begin{array}{l}\text { Socio } \\
\text { Demographic } \\
\text { Data }\end{array}$} & \multirow[t]{2}{*}{ Categories } & \multicolumn{3}{|l|}{ BMI } & \multirow{2}{*}{$\begin{array}{l}\text { Total } \\
(320)\end{array}$} & \multirow[t]{2}{*}{$\%$} & \multirow{2}{*}{$\begin{array}{l}\mathrm{P} \\
\text { value }\end{array}$} \\
\hline & & $\mathrm{BMI}<25$ & $\begin{array}{l}\text { BMI 25- } \\
30\end{array}$ & $\mathrm{BMI}>30$ & & & \\
\hline \multirow[t]{3}{*}{ Age Group } & $16-25 \mathrm{yrs}$ & 98 & 20 & 20 & 138 & 43.1 & \multirow[t]{3}{*}{0.000} \\
\hline & $26-35$ yrs & 36 & 22 & 52 & 110 & 34.4 & \\
\hline & $36-45$ yrs & 24 & 8 & 40 & 72 & 22.5 & \\
\hline \multirow[t]{6}{*}{ Education } & Illiterate & 30 & 0 & 0 & 30 & 9.4 & \multirow[t]{6}{*}{0.000} \\
\hline & primary school & 66 & 20 & 32 & 118 & 36.9 & \\
\hline & intermediate school & 24 & 20 & 10 & 54 & 16.9 & \\
\hline & secondary school & 0 & 0 & 10 & 10 & 3.1 & \\
\hline & Institute & 26 & 10 & 30 & 66 & 20.6 & \\
\hline & College & 12 & 0 & 30 & 42 & 13.1 & \\
\hline \multirow[t]{2}{*}{ Occupation } & employed & 12 & 0 & 0 & 12 & 3.7 & \multirow[t]{2}{*}{0.000} \\
\hline & house wife & 146 & 50 & 112 & 308 & 96.3 & \\
\hline \multirow[t]{3}{*}{ INCOME } & $>500000$ dinar & 94 & 18 & 40 & 152 & 47.5 & \multirow[t]{3}{*}{0.000} \\
\hline & $\begin{array}{lll}500000 & - & 1000000 \\
\text { dinar } & & \\
\end{array}$ & 52 & 32 & 72 & 156 & 48.8 & \\
\hline & $>1000000$ dinar & 12 & 0 & 0 & 12 & 3.7 & \\
\hline \multirow[t]{3}{*}{ Durations } & $<5$ years & 78 & 30 & 42 & 150 & 46.9 & \multirow[t]{3}{*}{0.000} \\
\hline & $5-10$ years & 54 & 10 & 60 & 124 & 38.7 & \\
\hline & $>10$ years & 26 & 10 & 10 & 46 & 14.4 & \\
\hline \multirow[t]{2}{*}{ Smoking } & $\mathrm{No}$ & 134 & 50 & 112 & 296 & 92.5 & \multirow[t]{2}{*}{0.000} \\
\hline & Yes & 24 & 0 & 0 & 24 & 7.5 & \\
\hline \multirow[t]{2}{*}{ Medication } & No & 0 & 10 & 10 & 20 & 6.3 & \multirow[t]{2}{*}{0.000} \\
\hline & Yes & 158 & 40 & 102 & 300 & 93.7 & \\
\hline \multirow{2}{*}{$\begin{array}{l}\text { Chronic } \\
\text { illness }\end{array}$} & No & 158 & 50 & 92 & 300 & 93.7 & \multirow[t]{2}{*}{0.000} \\
\hline & Yes & 0 & 0 & 20 & 20 & 6.3 & \\
\hline \multirow[t]{4}{*}{ Religion } & Nil & 68 & 0 & 0 & 68 & 21.3 & \multirow[t]{4}{*}{0.000} \\
\hline & Mild & 10 & 20 & 22 & 52 & 16.3 & \\
\hline & Moderate & 70 & 20 & 50 & 140 & 43.7 & \\
\hline & Sever & 10 & 10 & 40 & 60 & 18.7 & \\
\hline \multicolumn{2}{|l|}{ Total } & $158(49.4 \%)$ & $50(15.6 \%)$ & $112(35 \%)$ & 320 & $100 \%$ & \\
\hline
\end{tabular}


Table 2: correlation of depression with sociodemographic characteristics of infertile women

\begin{tabular}{|c|c|c|c|c|c|}
\hline \multirow{2}{*}{$\begin{array}{l}\text { Socio Demographic } \\
\text { Data }\end{array}$} & \multirow[t]{2}{*}{ Categories } & \multicolumn{2}{|l|}{ DSM } & \multirow[t]{2}{*}{ Total } & \multirow[t]{2}{*}{$\mathrm{P}$ value } \\
\hline & & NEGATIVE & POSITIVE & & \\
\hline \multirow[t]{3}{*}{ Age Group } & $16-25 \mathrm{yrs}$ & 22 & 116 & 138 & \multirow[t]{3}{*}{0.062} \\
\hline & $26-35$ yrs & 30 & 80 & 110 & \\
\hline & $36-45$ yrs & 12 & 60 & 72 & \\
\hline \multirow[t]{6}{*}{ Education } & illiterate & 10 & 20 & 30 & \multirow[t]{6}{*}{0.000} \\
\hline & primary school & 22 & 96 & 118 & \\
\hline & intermediate school & 12 & 42 & 54 & \\
\hline & secondary school & 10 & 0 & 10 & \\
\hline & institute & 10 & 56 & 66 & \\
\hline & college & 0 & 42 & 42 & \\
\hline \multirow[t]{2}{*}{ Occupation } & employed & 0 & 12 & 12 & \multirow[t]{2}{*}{0.065} \\
\hline & house wife & 64 & 244 & 308 & \\
\hline \multirow{3}{*}{$\begin{array}{l}\text { Monthly income } \\
\text { ID }\end{array}$} & $>500000$ & 22 & 130 & 152 & \multirow[t]{3}{*}{0.005} \\
\hline & $500000-1000000$ & 42 & 114 & 156 & \\
\hline & $>1000000$ & 0 & 12 & 12 & \\
\hline \multirow[t]{3}{*}{ Marriage Durations } & $<5$ years & 10 & 140 & 150 & \multirow[t]{3}{*}{0.000} \\
\hline & $5-10$ years & 42 & 82 & 124 & \\
\hline & $>10$ years & 12 & 34 & 46 & \\
\hline \multirow{2}{*}{ Smoking } & No & 52 & 244 & 296 & \multirow[t]{2}{*}{0.001} \\
\hline & Yes & 12 & 12 & 24 & \\
\hline \multirow[t]{2}{*}{ Medication } & No & 0 & 20 & 20 & \multirow[t]{2}{*}{0.010} \\
\hline & Yes & 64 & 236 & 300 & \\
\hline \multirow[t]{2}{*}{ Chronic illness } & No & 64 & 236 & 300 & \multirow[t]{2}{*}{0.010} \\
\hline & Yes & 0 & 20 & 20 & \\
\hline \multirow[t]{4}{*}{ Religion } & Nil & 10 & 58 & 68 & \multirow[t]{4}{*}{0.000} \\
\hline & Mild & 0 & 52 & 52 & \\
\hline & moderate & 44 & 96 & 140 & \\
\hline & sever & 10 & 50 & 60 & \\
\hline \multirow[t]{3}{*}{ BMI } & $\mathrm{BMI}<25$ & 34 & 124 & 158 & \multirow[t]{3}{*}{0.000} \\
\hline & BMI 25-30 & 0 & 50 & 50 & \\
\hline & BMI > 30 & 30 & 82 & 112 & \\
\hline \multicolumn{2}{|l|}{ Total } & 64 & 256 & 320 & \\
\hline
\end{tabular}

Table 3: range, mean, and standard deviation of infertile women characteristics

\begin{tabular}{|l|l|l|l|l|}
\hline & Minimum & Maximum & Mean & Std. Deviation \\
\hline Age & 17.00 & 42.00 & 28.3744 & 7.10600 \\
\hline Income monthly & 150000.00 & 1500000.00 & 584140.9692 & 309367.42045 \\
\hline Height & 142.00 & 174.00 & 161.6476 & 6.80469 \\
\hline Weight & 50.00 & 130.00 & 73.0220 & 14.90202 \\
\hline BMI & 17.72 & 42.94 & 28.0021 & 5.46759 \\
\hline Marriage duration & 1.00 & 20.00 & 6.9119 & 4.52232 \\
\hline
\end{tabular}

Table 4: the correlation of BMI of infertile women with depression

\begin{tabular}{|c|c|c|c|c|c|c|c|}
\hline & & \multicolumn{3}{|l|}{ BMI } & \multirow{2}{*}{$\begin{array}{l}\text { Total } \\
(320)\end{array}$} & \multirow[t]{2}{*}{$\%$} & \multirow[t]{2}{*}{$\mathrm{P}$ value } \\
\hline & & $\begin{array}{l}\mathrm{BMI}<25 \\
158(49.4 \%)\end{array}$ & $\begin{array}{l}\text { BMI 25- } \\
30 \\
50(15.6 \%)\end{array}$ & $\begin{array}{l}\text { BMI > 30 } \\
112(35 \%)\end{array}$ & & & \\
\hline \multirow[t]{2}{*}{ SRQ_20 } & NEGATIVE & $34(21.5 \%)$ & 0 & $30(26.8 \%)$ & 64 & 20 & \multirow[t]{2}{*}{0.000} \\
\hline & POSITIVE & $124(78.5 \%)$ & $50(100 \%)$ & $82(73.2 \%)$ & 256 & 80 & \\
\hline \multirow[t]{2}{*}{ DSM } & NEGATIVE & $34(21.5 \%)$ & 0 & $30(26.8 \%)$ & 64 & 20 & \multirow[t]{2}{*}{0.000} \\
\hline & POSITIVE & $124(78.5 \%)$ & $50(100 \%)$ & $82(73.2 \%)$ & 256 & 80 & \\
\hline \multirow{5}{*}{$\begin{array}{l}\text { HAM } \\
\text { depression } \\
\text { Degree }\end{array}$} & no depression & $34(21.5 \%)$ & 0 & $30(26.8 \%)$ & 64 & 20 & \multirow[t]{5}{*}{0.000} \\
\hline & mild depression & $26(16.5 \%)$ & $18(36 \%)$ & $14(12.5 \%)$ & 58 & 18.1 & \\
\hline & moderate depression & $30(19 \%)$ & $10(20 \%)$ & 0 & 40 & 12.5 & \\
\hline & severe depression & $30(19 \%)$ & $10(20 \%)$ & $42(37.5 \%)$ & 82 & 25.6 & \\
\hline & very severe depression & $38(24 \%)$ & $12(24 \%)$ & $26(23.2 \%)$ & 76 & 23.8 & \\
\hline
\end{tabular}




\section{Discussion:-}

Study found $80 \%$ of women with primary infertility were depressed. High prevalence of depression might be explained by that; in our culture, women always blamed for causes of infertility. Gynecologists are hurry to attribute couple infertility to women factors. Infertile women suffer social pressure from their relatives and friend. Infertility constitutes a crisis and stigma in affected women, may become isolated and neglected. The reactions may include; frustration, shock, anger, depression, and grief, loss of self-esteem, self-confidence. Infertile women may avoid social interaction with friends who are pregnant and families who have children.

Current study found depression of primary infertile women was significantly associated with; education, monthly income, duration of marriage, smoking, medication, chronic illness, religion, and BMI. This association might be explained by the fact that the longer the infertility crisis continues, the more people in families and neighbors will know about it lead to more social pressure women will feel; another possible explanation is that longer infertility duration and repeated referrals would gradually change infertility to a chronic problem.

Current study Findings was lower than the results of a study conducted in Pakistan ${ }^{17}$ which showed depression was $95 \%$ in infertile women. Findings of current study were higher than many studies. The study done in Morocco ${ }^{18}$ showed that $55 \%$ of the women had depression with positive relation to occupation. Nigerian study ${ }^{19}$ depression was $54.5 \%$ of infertile women. Iranian study in $\mathrm{Tehran}^{20}$ found $30.5 \%$ of infertile women had depression with significant association to infertility duration and failure in previous treatment. Survey carried in Katowice, Poland ${ }^{21}$ found $(22.52 \%)$ of women had light severity of depression. Chinese study in Guangdong Province 22 showed depression was $47.0 \%$ of infertile females. Nigerian study in Ogbomoso $^{23}$ found a prevalence of infertile female depression of $52.7 \%$, with no significant association between the age group, level of education, duration of marriage, type of infertility. Indian study ${ }^{24}$ showed depression in $41 \%$ of the infertile females which was correlated with duration of infertility, positive related to occupation and duration of infertility.

Current study prevalence of depression among infertile couples was higher than many studies. Drosdzol 2009 found females: $35.4 \%{ }^{25}$. Farzadi 2008 females: $72.54 \%{ }^{26}$. Ramezanzadeh 2004 females: $40.8 \%{ }^{27}$. Domar 1992 females: $36.7 \%^{28}$. Haririan 2010: depression among infertile females was $58 \%{ }^{29}$. Peyvandi 2010: depression among infertile females was $62 \%{ }^{30}$ One of the factors associated with both depression and infertility is BMI. The study showed that

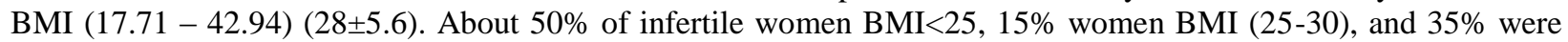
BMI $>30$. BMI found of statistical significant correlation with sociodemographic characteristics of women involved in the study $(P<0.001)$. The study found statistical significant correlation of depression with BMI $(P<0.001)$. A review by Jungheim et al. ${ }^{31}$, reported that 35.8 percent of menstruating women had a higher than normal BMI, with a mean BMI of $28.7 \mathrm{~kg} / \mathrm{m}^{2}$. Previous studies have shown conflicting findings, with some indicating that obesity is related to higher depressive symptoms ${ }^{32}$, others found no association between obesity and depression ${ }^{33}$, and others found that obesity was related to lower depressive symptoms ${ }^{34}$. A meta-analysis synthesizing the results from the previous community-based studies found a modest association between obesity and depression ${ }^{35}$. Most of the studies identified a stronger relationship between obesity and depression in women, and in individuals with lower educational level ${ }^{36}$. Other studies have demonstrated that this relationship changes according to ethnicities and races $^{37}$.

Behavioral mechanisms such as functional impairment and repeated dieting, cognitive mechanisms, such as body image dissatisfaction (BID) and poor self-rated health, and social mechanisms, such as stigma, may all play a role in the pathway from obesity to depression. Regarding obesity causing depression there may be a direct pathway through the biological effect of increased stress reactivity with hormonal change, and an indirect pathway through which mechanisms, such as poor adherence, binge eating, negative thoughts, and reduced social support, make it more difficult for the depressed person to care for themselves effectively, leading to weight gain.

The reported prevalence of depressive disorders varies across cultures. Studies, with different population and designs: Cohort study, cross sectional, interviews, case control and systematic review discussed the infertility and depression. Diversity in sample size, selection methods, diagnostic tools and questionnaire used, duration of collecting data also affected the results.

In conclusion, current study found high prevalence of depression among infertile women $80 \%$. Depression was significantly associated with BMI. Depression was significantly associated with education, monthly income, duration of marriage, smoking, medication, chronic illness, and religion. BMI was significantly associated with age, education, occupation, monthly income, duration of marriage, smoking, medication, chronic illness, and religion. 


\section{Acknowledgment:-}

Special thanks to the participants for their patience and kindness.

Conflict of interest: The author declare no conflicts of interest

\section{References:-}

1. Mart'in A R, Ruiz J P N, Nieto J M M , Jim'enez L E, "Life-style factors associated with overweight and obesity among Spanish adults," Nutricion Hospitalaria (2009)vol. 24, no. 2, pp. 144-151,.

2. Koski, M., Naukkarinen, H. Severe Obesity, Emotions and Eating Habits: A Case-Control Study. BMC Obesity (2017), 4, 2. https://doi.org/10.1186/s40608-016-0138-9

3. Milaneschi, Y., Simonsick, E.M., Vogelzangs, N., Strotmeyer, E.S., Yaffe, K., Harris, T.B., Tolea, M.I., Ferrucci, L. and Penninx, B.W. Leptin, Abdominal Obesity, and Onset of Depression in Older Men and Women. Journal of Clinical Psychiatry (2012), 73, 1205-1211. https://doi.org/10.4088/JCP.11m07552

4. Tashakori A, Riahi F, Mohammadpour A., The Relationship between Body Mass Index and Depression among High School Girls in Ahvaz. Advances in Medicine. Volume 2016, Article ID 3645493, 5 pages http://dx.doi.org/10.1155/2016/3645493

5. Wyatt S B, Winters K P, Dubbert P M, "Overweight and obesity: prevalence, consequences, and causes of a growing public health problem," The American Journal of the Medical Sciences (2006), vol. 331, no. 4, pp. 166-174,

6. Al-Abbudi SJR, Prevalence and Assessment of Depression among Diffuse Idiopathic Skeletal Hyperostosis (DISH) patients. Clin Psychiatry (2019) Vol.4 No.3:12

7. Al Abbudi SJR, Ezzat KI, Farhan MS, Zebala AA, Al-Beedany MSJ, et al. Prevalence and determinants of depression among traumatic spinal cord injured patients attending Ibn-Al-Quff Hospital, Baghdad, Iraq. Iraqi J Med Sci (2017) 15: 383-395.

8. Adams G B, Murcia A. The association between obesity, depression, and anxiety: Evidence from a community health needs assessment survey. J Ga Public Health Assoc (2016) Vol 5, No. 3: 274-278

9. Luppino, F., de Wit, L., Bouvy, P., Stijnen, T., Cuijpers, P., Penninx, B., \& Zitman, F.. Overweight, Obesity, and Depression: A Systematic Review and Meta-analysis of Longitudinal Studies. Archives of general psychiatry (2010), 67(3), 220-229.

10. Montazeri A, Mousavi S J, Omidvari S, Tavousi M, Hashemi M, Rostami T, "Depression in Iran: a systematic review of the literature (2000-2010)," BMC Psychiatry 2013, vol. 6, pp. 567-594,.

11. Sadock B J, Sadock V A, Ruiz P, Kaplan \& Sadock Synopsis of Psychiatry: Behavioral Sciences/Clinical Psychiatry,Wolters Kluwer, Philadelphia, Pa, USA, 2015,11th edition,.

12. Neki N S. Obesity and Depression:-Is There Any Link? JK SCIENCE 2013Vol. 15 No. 4, Oct-December

13. Ozgoli G, Sheikhan Z, Zahiroddin A, Nasiri M, Amiri S, Kholosi Badr F. Evaluation of the Prevalence and Contributing Factors of Psychological Intimate Partner Violence in Infertile Women. Journal of Midwifery and Reproductive Health (2016) 4(1): 571-581

14. Rashidi B, Hosseini S, Beigi1 P, Ghazizadeh M, Farahani M. Infertility stress: the role of coping strategies, personality trait, and social support. Journal of Family and Reproductive Health(2011). 5(4):101-108.

15. Aldemir S, Eser A, Turhan NO, Dalbudak E, Topcu M, Relation of anxiety and depressive symptoms with perceived social support according to gender within infertile couples. Dusunen Adam The Journal of Psychiatry and Neurological Sciences (2015) 28:328-336 DOI: 10.5350/DAJPN2015280404

16. Al-Abbudi S J R, Hashim M T, Pattern of Psychiatric Morbidity and Substance Abuse among Iraqi Prisoners. Journal of Addiction Research, (2019) Volume 3 | Issue 1 | 1 - 9

17. Qayyum M, Ahmed S, Kanwal S, Ishfaq Y, Hassan H, et al. Frequency of depression among fertile and infertile women. PAFMJ (2014)64: 2.

18. Benbella A, Ktiri F, Kasouati J, Aboulmakarim S, Hardizi H, et al. Depression and Anxiety Among Infertile Moroccan Women: A Cross-Sectional Study in the Reproductive Health Center in Rabat. J Depress Anxiety (2018) 7: 312. doi:10.4172/2167-1044.1000312

19. Owonikoko Kola M, Bobo Temidayo I, Tijani Aramide M, Atanda Oluseyi O. Adversities of Being an Infertile Woman in Ogbomoso - A Semi Urban Town in Nigeria. Ann Infert Rep Endocrin. 2018; 1(1): 1006.

20. Samani R.O., et al., Prevalence of depression and its determinant factors among infertile patients in Iran based on the PHQ-9, Middle East Fertil Soc J (2018), https://doi.org/10.1016/j.mefs.2018.03.002

21. Szanecki1W., et al. Impact of infertility on mental health and female sexuality of women undergoing therapy of assisted reproductive technology, Przegląd Lekarski 2018;75(06)275-278 
22. Ma F, Cao H, Song L, Liao X, Liu X. Study on risk factors for depression in female infertile patients and evaluation of efficacy of psychological nursing intervention, Int J Clin Exp Med 2018;11(4):4030-4038

23. Oladeji SA, OlaOlorunAD, Depression among infertile women in Ogbomosoland, South African Family Practice, (2017): DOI:10.1080/20786190.2017.1370840

24. GargN, Suthar N, Goyal M, Khuteta R P, Depression Among Infertile And Fertile women At A Tertiary CentreA Comparative Study. IOSR Journal of Dental and Medical Sciences (IOSR-JDMS) (May. 2017) Volume 16, Issue 5 Ver. III, PP 125-130 DOI:10.9790/0853-160503125130

25. Drosdzol A., Skrzypulec V., Depression and anxiety among Polish infertile couples-an evaluative prevalence study, J. Psychosom. Obstet. Gynaecol. 30 (2009) 11-20.

26. Farzadi L., Ghasemzadeh A., Two main independent predictors of depression among infertile women: an Asian experience, Taiwan J. Obstet. Gynecol. 47 (2008) 163-167.

27. Ramezanzadeh L, AghssaM.M., Abedinia N., Zayeri F., Khanafshar N., Shariat M., Jafarabadi M., A survey of relationship between anxiety, depression and duration of infertility, BMC Womens Health 4 (2004) 1.

28. Domar A.D., Broome A, Zuttermeister P. C., Seibel M, Friedman R., The prevalence and predictability of depression in infertile women, Fertil. Steril. 58 (1992) 1158-1163.

29. Haririan HR, Mohammadpour Y, Aghajanloo A. Prevalence of depression and contributing factors of depression in the infertile women referred to Kosar Infertility Center, 2009. Int J Gynecol Obstet, (2010)13(2): 45-9.

30. Peyvandi S, Hosseini SH, Daneshpoor SMM, Mohammadpour RA, Qolami N. The prevalence of depression, anxiety and marital satisfaction and related factors in infertile women reffered to infertility clinics of Sari city in 2008. Journal of Mazandaran University of Medical Sciences, (2010)20(80): 26-32.

31. Nghiem, S., Vu X B, Barnett A, Trends and determinants of weight gains among OECD countries: an ecological study. Public Health,2018. 159: p. 31-39.

32. Johnston E, Johnson S, McLeod P, Johnston M The relation of body mass index to depressive symptoms. Can J Public Health (2004) 95(3):179-183

33. Ohayon MM, Hong S-C Prevalence of major depressive disorder in the general population of South Korea. J Psychiatr Res (2006) 40(1):30-36

34. Carpenter KM, Hasin DS, Allison DB, Faith MS Relationships between obesity and DSM-IV major depressive disorder, suicide ideation, and suicide attempts: results from a general population study. Am J Public Health (2000) 90(2):251

35. de Wit L, Luppino F, van Straten A, Penninx B, Zitman F, Cuijpers P Depression and obesity: a meta-analysis of community- based studies. Psychiatry Res (2010) 178(2):230-235

36. Preiss K, Brennan L, Clarke D A systematic review of variables associated with the relationship between obesity and depression. Obes Rev (2013) 14(11):906-918

37. Hicken MT, Lee H, Mezuk B, Kershaw KN, Rafferty J, Jackson JS. Racial and ethnic differences in the association between obesity and depression in women. J Womens Health (2013) 22(5):445-452. https://doi.org/10.1089/jwh.2012.4111 